\title{
The Influence of Time Budget Pressure, Audit Complexity and Audit Fee on Audit Quality (Case Study at Public Accounting Firms in Bali Province)
}

\author{
I Gusti Agung Gde Adhi Raditya ${ }^{1}$, Made Yeni Latrini ${ }^{2}$, Ni Luh Sari Widhiyani ${ }^{3}$ \\ Faculty of Economics and Business, Udayana University, Bali, Indonesia \\ Email: adhiraditya11@gmail.com, madeyeni37@gmail.com
}

\begin{abstract}
The research objective is to empirically examine the influence of time budget pressure, audit complexity, and audit fees on audit quality. The study was conducted at the Public Accounting Firm in Bali in 2020. The sample obtained was 32 auditors. The sampling method used is the census method. The data analysis technique used is multiple regression. The results of the study namely time budget pressure has negative effect on audit quality. This means that an increase in time budget pressure will have an impact on the decline in audit quality. Audit complexity has negative effect on audit quality. This means that the higher the audit complexity possessed by an auditor results in decreased audit quality. Audit fee has positive effect on audit quality. This means that the higher the audit fee, the audit quality will be better.
\end{abstract}

Keywords: time budget pressure, audit complexity, audit fee, audit quality

\section{Introduction}

Financial statements are management responsibilities that need to be audited by public accountants as an independent third party outside the company to avoid mistakes that occur, both intentional and unintentional. If the financial statements have not gone through an audit process, then the reports are not trusted by the parties concerned. The audited financial statements and obtain unqualified opinion from the Public Accounting Firm (PAF), means that users of financial statements can be sure that the financial statements are free from material misstatements and are presented in accordance with accounting principles in force in Indonesia, thereby increasing user confidence financial statements. A good audit quality will produce financial reports that can be trusted and can be the basis for decision making by other parties such as investors, besides, there are fears of a widespread financial scandal, which can erode public confidence in the audited financial statements and the public accounting profession (Setyawati and Rosiana, 2015). Auditors in conducting audits are required to be able to complete their work on time in accordance with the time agreed with the client. Quality report demands with time budget pressure is a separate pressure for auditors (Khadilah, Purnamasari and Gunawan, 2015)

Time budget pressure on audit quality is always exist and an auditor is required to be able to work efficiently but does not violate or ignore the audit procedures in effect so that the resulting audit is of high quality. Aisyah (2017) shows that "time budget pressure has a negative effect on audit quality. The high time pressure in conducting audits, making auditors do not always audit based on procedures and planning in accordance with applicable regulations."

The complexity of auditing can be interpreted as a complex task, confusing and difficult to measure objectively because each individual's perception is different. It depends on how each individual responds to the difficulty of the task given. Complexity arises from ambiguity and weak structure, both in the main tasks and other tasks. In confusing and unstructured tasks, alternatives cannot be identified, so data cannot be obtained and results cannot be predicted.

An auditor works in carrying out audits of his client's financial statements which is his responsibility also due to the desire to get compensation in return, which is often referred to as an audit fee. Audit fees are costs that depend on the risk of the assignment, the complexity of the services provided, the level of expertise required to carry out the services, the PAF fee structure concerned and other professional considerations. If the auditor's fee is not in accordance with the characteristics of the determination of the amount of the audit fee, then it is suspected that the motivation to work on the audit process cannot be maximized.

The purposes of these study are : (1) to explain the influence of time budget pressure on audit quality at public accounting firms in Bali. (2) to explain the influence of audit complexity on audit quality at public accounting firms in Bali, and (3) to explain the influence of audit fees on audit quality at public accounting firms in Bali. Researchers hope that by doing this research can provide theoretical as well as practical benefits. Theoretical benefits can contribute to the development of theory and can be used by subsequent researchers as a reference in research. Practical benefits can benefit public accounting firms and auditors in maintaining professionalism and independence in order to improve the quality of audits produced. 


\section{Literature Review}

\subsection{Agency Theory, Agency Conflict and Behavioral Theory}

Agency theory is a theory that describes the relationship between two individuals who have different interests, namely principals and agents. The agency relationship is a contractual relationship between principals and agents, principals delegate certain tasks in accordance with the agreed contract or decision making to the agent. The agent will do the best for the interests of the principals. Principals will reward the work of the agent. The authority and responsibilities of agents and principals are regulated in a work contract with mutual agreement (Aisyah, 2017). In agency theory, auditors are those who are considered capable of mediating the interests of the principal and agents in managing the company's finances. The independent auditor also functions to reduce the occurrence of agency problems arising from selfish behavior carried out by the agent. Behavioral theory is a study of human behavior. Psychology and social psychology contribute a lot in the development of behavior, namely personality, attitudes, motivation, perception, values, and learning. In connection with the explanation above, this theory tries to explain about aspects of human behavior in organizations, especially auditors, namely examining how the behavior of auditors with the interaction of time limits affect the final audit results.

\subsection{Audio Quality}

According to Anugrah et al. (2017) audit quality relates to the responsibility of auditor for the availability of financial statements that does not contain material errors or fraud coverage. Questioning the auditor's accountability process must absolutely not make mistakes in his audit. An auditor is expected to produce a quality audit. Quality audit shows that the auditor's performance is good, because to produce a quality audit the auditor must really meet the general standards and quality control standards that have been set. This is in accordance with, the Indonesian Institute of Accountants in the Public Accountants Professional Standards (SPAP) which states that an audit conducted by an auditor is said to be of quality if it meets auditing standards and quality control standards. Auditing standards relate to the implementation of individual audit assignments, while quality control standards relate to the implementation of overall PAF audit practices. Thus, if the auditor in conducting an audit meets the audit standards and quality control standards, the audit he conducts can be said to be a quality audit

\subsection{Time Budget Pressure}

Time budget pressure is the period of time the auditor has to carry out the audit process at the client company. Time budget pressure is related to the pressure experienced by the auditor when trying to complete the audit work with the budgeted time. When facing time budget pressure, auditors will respond in two ways, functional and dysfunctional. Time budget pressure is a condition when the auditor is required to make efficiency over the time budget that has been prepared or there is a very tight and rigid budget time discussion (Nirmala and Cahyonowati, 2015). Some accountants consider that time budgets are often unrealistic, but they also still have to have the responsibility of meeting the time budgets to progress professionally. The high time pressure in conducting audits, makes the auditor increasingly improve efficiency in auditing so that often the audit carried out by the auditor is not always based on procedures and planning in accordance with applicable regulations. Auditors in conducting audits are required to be able to complete their work on time in accordance with the time agreed with the client.

\subsection{Audit Complexity}

The complexity of the audit is the process of each individual in dealing with the difficulty of a task caused by the limitations of capabilities and memory and the ability to integrate the problems owned by decision makers. Increasing complexity in a task or system will reduce the success rate of that task. Sanusi et al. (2017) show that when the auditor has complex or unstructured tasks, no matter how high the auditor's effort will be difficult to complete the work properly, it will actually reduce the auditor's performance. Ginting and Hidayat (2019) found that task complexity causes a decrease in performance if the auditor has low knowledge, but does not affect the performance of auditors who have high knowledge. Related to auditing activities, the high complexity of this audit can cause accountants to behave disfunctionally, causing a decline in audit quality

\subsection{Audit Fee}

Many theories that define related to audit fees. One of them comes from De Angelo (Alm, 2019), which states that "audit fees are income whose amount varies because it depends on several factors in the audit assignment such as, the size of the client company, the complexity of audit services faced by the auditor, audit risk faced by the auditor from the client and name PAF that performs audit services." Audit fees paid by the client to the auditor are a form of remuneration provided by the auditor to the client and as a form of compensation for the amount of the loss costs incurred during the audit. According to Aditama and Utama (2015), "audit fees are revenue that varies depending on several factors in the audit assignment such as: client finance, 
company size, auditor size and public accounting firm, auditor's expertise in the industry, and efficiency owned by the auditor"

\subsection{Hyphotesis Development}

Behavioral theory explains the relationship between time budget pressure variables and audit quality. When facing a deadline, the auditor will respond in two ways, namely, functional and dysfunctional. So with a deadline can affect the behavior of auditors which then causes a decrease in audit quality. Audit quality can get worse, if the budgeted time allocation is not realistic with the complexity of the audit it is carrying. If the specified time allocation is very limited, then there is the possibility that auditors compensate their work quickly and only focus on important tasks so as to produce poor performance that will have an impact on the quality of audits produced. Research conducted by Ratha and Ramantha (2015), Pratama and Merkusiwati (2015) states that there is a negative relationship between the influence of time budget pressure on audit quality which is said the higher time pressure applied to the auditor can reduce the quality of the audit.

H1: Time budget pressure has a negative effect on audit quality.

Agency conflict that occurs between agent and principal in agency theory can be mitigated by the existence of an independent third party who mediates the interests of both parties, namely external auditors or public accountants. The public accountant is tasked with assessing the existence of information asymmetry or manipulation that occurs. Public accountant is the party in charge of monitoring and evaluating the performance of the agent, whether it has acted in accordance with the interests of the principal through

Increasing complexity in a task or system will reduce the success rate of that task. Anugrah et al. (2017) in his study stated that the higher the complexity of the audit conducted, the audit quality can decrease

$\mathrm{H} 2$ : The complexity of the audit has a negative effect on audit quality

This Agency Theory explains "the relationship between audit fee variables and audit quality." Principals want the final results of decisions that produce maximum profit or increase the value of investment in the company. Pramesti and Wiratmaja (2017) found evidence that when the auditor negotiates with the management of his client's company related to the amount of fees that must be paid, it is likely that mutual cooperation will occur with clear rules, where this situation will reduce the quality of audited reports. So the amount of audit fees to be received by this auditor, will have an influence on audit quality. This is also supported by research conducted by Andriani and Nursiam (2018), which shows that "there is a significant influence between audit fees and audit quality. The effect of audit fees on audit quality has a positive effect. If the audit fee is higher the audit quality will be higher as well, and vice versa. If the audit fees paid by management are low, the audit quality will be even lower."

H3: Audit Fee has a positive effect on audit quality

\section{Research Methods}

This research is a quantitative research with associative type. The object of research is the attribute or nature or value of people, objects or activities that have variations that are determined by researchers to be studied and conclusions drawn. The objects in this study are audit quality, time budget pressure, audit complexity and audit fees. The dependent variable used is audit quality (Y). The independent variable is a variable that can cause changes to the dependent variable. Three independent variables are used, namely time budget pressure (X1), audit complexity (X2) and audit fee (X3).

Audit quality is important in auditing. The quality of an auditor can be seen through the application of accounting standards and auditing standards that are correct so that violations committed by clients can be revealed and reported. Indicators on this variable consist of the amount of compensation from the client, understanding of the client's accounting information system, the level of timeliness in completing the audit, the level of compliance with the Public Accountant Professional Standards in carrying out field work, the level of confidence in the client's statement, and the level of caution in decision making during the audit process.

Time budget pressure is defined as a condition that indicates that the auditor is required to make efficiency over the time budget that has been prepared or there is a very tight or rigid budget time limitation. Indicators of this variable consist of limited assignment time and understanding of time budget. The instrument used in measuring time budget pressure consists of eight statement items adopted from a questionnaire in the Ratha and Ramantha (2015). Audit Complexity (X2). Audit complexity is an individual's perception of the difficulty of a task caused by the limited capability and memory and the ability to integrate the problems possessed. The indicators in this variable consist of the difficulty of the task and the structure of the task at hand. The instrument used to examine consisted of six statements adopted from a questionnaire in the Ratha and Ramantha (2015).

Audit fee is "the amount of income received by the auditor, the amount of which varies depending on the 
Vol.2, Issue 1, pp.27-32, 2020

Available online at: https://tljbm.org/jurnal/index.php/tljbm

financial and size of the client company, the complexity of the audit service, audit risk, the auditor's level of expertise, the efficiency of the auditor and the name of the PAF who performs the audit service."

Based on the type, the data used in this study are as follows: Quantitative data is data in the form of numbers. This study uses quantitative data in the form of the number of auditors working on each PAF as well as the results of the questionnaire measured using the Modified Likert scale. Qualitative data is data in the form of schemes, words or images. This study uses qualitative data in the form of PAF names in the Province of Bali, general description of PAF Province of Bali, and organizational structure of PAF Province of Bali.

Based on the source, the data used in this study are as follows: Primary data, data obtained directly from the original source (not through intermediary media). This data was obtained through respondents' statements in answering the questionnaire. Secondary data, is a source of research data obtained indirectly through intermediary media. General description of PAF, number of auditors, and organizational structure in PAF Bali Province is secondary data used in research. Population in this study are all auditors who work at PAF Bali Province.

The method of determining the sample is saturated sampling or it often calls as census method. The reason for using this method is because the population is the auditor, both senior and junior auditors studied, with a relatively small number of 32 people so that the entire population will be respondents in this study. This study uses primary data collection methods, namely questionnaires in the form of a list of questions that will be given to respondents. This questionnaire is about time budget pressure, audit complexity, audit fees, and audit quality. The results of the questionnaire will be measured using a Modified Likert scale, where the respondent's answer choices are scored on a 7-point scale. Data analysis technique used for problem solving in this study is multiple linear regression analysis technique

\section{Results}

Profile of respondents consist of gender, age, position, education, and length of time the auditor worked. According to the gender of the majority of respondents are male as much as 53\%. For the proportion of age, the majority of respondents aged $<26$ years were $75 \%$. While the proportion for the length of work of auditors who dominated were respondents with a length of work> 1 of $69 \%$. In terms of education, the majority of respondents with a Bachelor's level of education were $66 \%$. Of the 32 respondents, $59 \%$ are junior auditors.

Tabel 1. Result of the Multiple Linear Regression

\begin{tabular}{llllll}
\hline \multirow{2}{*}{ Variable } & \multicolumn{2}{l}{$\begin{array}{l}\text { Unstandardized } \\
\text { Coefficients }\end{array}$} & $\begin{array}{l}\text { Standardized } \\
\text { Coefficients }\end{array}$ & & Sig. \\
\cline { 2 - 4 } & B & $\begin{array}{l}\text { Std. } \\
\text { Error }\end{array}$ & Beta & & \\
\hline (Constant) & 6.456 & 0.742 & & 8.699 & 0.000 \\
X1 & - & & & & \\
& 0.382 & 0.099 & -0.461 & -3.852 & 0.001 \\
X2 & - & & & & \\
& 0.254 & -0.090 & -0.316 & -2.830 & 0.009 \\
X3 & 0.356 & 0.110 & 0.285 & 3.254 & 0.003 \\
\hline
\end{tabular}

Source: Primary Data Processed, 2020

A constant value of 6.456 shows that if the value of time budget pressure (X1), audit complexity (X2) and audit fee (X3) are zero, the audit quality is 6.456 units. Coefficient value $\beta 1=-0,382$. This means that the time budget pressure increases, the audit quality will decrease by 0.382 units assuming the other independent variables are constant. Coefficient value $\beta 2=-0.254$. This means that if the complexity of the audit increases, the audit quality will decrease by 0.254 units assuming the other independent variables are constant. Coefficient value $\beta 3=0.356$. This means that the audit fee increases, the audit quality will increase by 0.356 units assuming the other independent variables are constant.

Adjusted $\mathrm{R}^{2}$ value is 0.843 , It explains that $84.3 \%$ of audit quality variations are influenced by variables : time budget pressure (X1), audit complexity (X2), and audit fees (X3), but the remaining $15.7 \%$ influenced by other factors outside the model

The feasibility test of the model shows whether all independent or independent variables included in the model have a joint influence on the dependent or dependent variable. By comparing the level of significance of each independent variable together with a significant level $\alpha=$ 0.05 . If the level of significance of the independent variables together smaller than the level of significance, the hypothesis is accepted meaning that the independent variables jointly influence the dependent variable. The model feasibility test results show that the calculated $\mathrm{F}$ count value is 16.703 with a significance of $0.000,(\alpha<0.05)$, so it can be concluded that this research model has fulfilled the prerequisite of the feasibility of the regression model.

$\mathrm{T}$ test is used to determine the effect of each independent variable partially on the dependent variable. Based on table 4.8, the t test results can be interpreted as follows: The variable time budget pressure (X1) has a significance level of $t$ of $-8,352$ smaller than 0.05 . This means that time budget pressure has a negative effect on audit quality. The audit complexity variable (X2) has a significance level of t of - 
2.830 smaller than 0.05 . This means that audit complexity has a negative effect on audit quality. Audit fee variable (X3) has a significance level $t$ of 3.254 greater than 0.05 . This means that audit fees have a positive effect on audit quality.

\section{Discussion}

Partial test results show the negative influence of time budget pressure on audit quality. These results accept the H1 hypothesis which states that time budget pressure has a negative effect on audit quality. The higher the time budget pressure possessed by an auditor results in a lower quality audit produced.

The results of this study are consistent with Saadah (2016) which shows that "time budget pressure has a negative effect on audit quality." Characteristics of the respondents' data showed that $79 \%$ of auditors at PAF in Bandung had a working period of more than 1 year, which meant they had work experience and professional abilities. The results of this study indicate that time budget pressure has a major influence in increasing expertise and knowledge. Time budget pressure is an important thing that every auditor must apply in carrying out his professional work in order to achieve adequate audit quality. The application of careful and thorough attitude contained in professional skills creates opportunities for auditors to obtain sufficient confidence for themselves to be able to provide a statement that the financial statements are free from material misstatements, whether that results from an unintentional mistake or an intentional fraud done (Valentina, 2017). The results of this study are in line with research by Aisyah (2017), "time budget pressure has a negative effect on audit quality."

Partial test results indicate "a negative influence on audit complexity on audit quality." This result accepts H2 hypothesis which states that "audit complexity has a negative effect on audit quality, the higher audit complexity possessed by an auditor results in lower audit quality."

Partial test results indicate "a positive effect of audit fees on audit quality." H3 hypothesis which states that "audit fees have a positive effect on audit quality, the higher audit fees owned by an auditor results in higher quality audit results is in line with it The results of this study are supported by research conducted by research conducted by Chrisdinawidanty et al. (2016), Hanjani and Rahardja (2015), said that "audit fees have a positive effect on audit quality due to the existence of an agreement to provide high service fees that can make auditors become enthusiastic to work in carrying out audit procedures correctly so as to improve the quality of audits produced."

\section{Conclusion and Implication}

Based on the results of the analysis and discussion carried out previously, it can be concluded as follows: (1)Time budget pressure has a negative effect on audit quality. This means that an increase in time budget pressure will have an impact on the poor quality of audits. (2)Audit complexity has a negative effect on audit quality. This means that the higher the audit complexity possessed by an auditor results in lower audit quality and (3) Audit fees have a positive effect on audit quality. This means that the higher audit fees the audit quality will be better.

The results of this study provide additional information and empirical evidence about how time budget pressure, audit complexity, and audit fees affect audit quality. In addition, the results of this study provide evidence that conflicts of interest that arise in agency relationships in agency theory can be minimized by conducting an audit. The role of the auditor is considered capable of mediating the interests of the principal (owner) and agent (management) in managing the company and reducing the occurrence of agency problems. The auditor in his role can produce good audit quality.

Based on the results of the analysis of the discussion, as well as the conclusions in this study, the recommendations that can be given through the results of this study in order to get better results, namely: PAF Bali Province is expected to always communicate the time budget based on an agreement with the client so that he can do the work right time and be able to provide accurate and quality audit report results. Auditors in PAF Bali Province are expected to always work based on audit complexity by increasing awareness that all tasks are important so they are able to provide accurate and quality audit report results and PAF who have provided appropriate fees for auditors are expected to be able to maintain it, because with adequate fees can improve work performance and increase auditor motivation which will ultimately result in good audit quality.

\section{Limitation and Future Research}

This study is not exempt from limitations. First, this study only uses small size of sample, which might not precisely represent the total population for better generalization Therefore, we recommend to increasing the number of sample for future research. Second, this research only uses questionnaire as data collection instrument which might not validly represent the right answers due to respondents might not provide the right information in order to protect their companies reputations. For this reason, we suggest that the collection for the same type of data need to adopt also indepth interview, focus group discussion and observation to cross check all information from the respondent.

\section{References}

Aditama, I. A. and Utama, I. M. K. (2015) 'Pengaruh Audit Fee, Non Audit Services dan Audit Tenure pada 
Independendi Auditor', E-Jurnal Akuntansi Universitas Udayana, 13(3), pp. 1164-1189.

Aisyah, F. (2017) 'Pengaruh Due Profesional Care, Time Budget Pressure, Etika Auditor Dan Fee Auditor Terhadap Kualitas Audit (Studi Empiris Pada Kantor Akuntan Publik Di Surakarta dan Semarang)', Jurnal Akuntansi, 1(1), pp. 120.

Alm, J. (2019) 'What Motivates Tax Compliance?', Journal of Economic Surveys, 33(2), pp. 353-388. doi: 10.1111/joes.12272.

Andriani, N. and Nursiam, N. (2018) 'Pengaruh Fee Audit, Audit Tenure, Rotasi Audit Dan Reputasi Auditor Terhadap Kualitas Audit (Studi Empiris Pada Perusahaan Manufaktur yang Terdaftar di Bursa Efek Indonesia Tahun 2013-2015)', Riset Akuntansi dan Keuangan Indonesia, 3(1), pp. 29-39. doi: 10.23917/reaksi.v3i1.5559.

Anugrah, I., Kamaliah, K. and Ilham, E. (2017) 'Pengaruh Time Budget Pressure, Kompetensi dan Independensi terhadap Kualitas Audit dengan Etika Profesi sebagai Variable Moderasi', Jurnal Online Mahasiswa Fakultas Ekonomi Universitas Riau, 4(1), pp. 1322-1336.

Chrisdinawidanty, Z. N., Tugiman, H. and Muslih, M. (2016) 'Pengaruh Etika Auditor dan Fee Audit Terhadap Kualitas Audit (Studi Kasus Pada Kantor Akuntan Publik Di Wilayah Bandung)', E-Proceeding of Management, 3(3), pp. $1-20$.

Ginting, C. U. and Hidayat, W. (2019) 'The effect of a fraudulent financial statement, firm size, profitability, and audit firm size on audit delay', International Journal of Innovation, Creativity and Change, 9(7), pp. 323-341.

Hanjani, A. and Rahardja (2015) 'Pengaruh etika auditor, pengalaman auditor, fee audit, dan motivasi auditor terhadap kualitas audit', E-Jurnal Universitas Diponegoro, 3(2), pp. $1-9$.

Khadilah, R., Purnamasari, P. and Gunawan, H. (2015) 'Pengaruh Time Budget Pressure, Pengalaman Auditor, Etika Auditor dan Kompleksitas Audit Terhadap Kualitas Audit', SPeSIA, 1(1), pp. 236-243.
Nirmala, R. P. . and Cahyonowati, N. (2015) 'Pengaruh Independensi, Pengalaman, Due Professional Care, Akuntabilitas, Komplesitas Audit, dan Time Budget Pressure terhadap Kualitas Audit (Studi Empiris pada Auditor KAP di Jawa Tengah dan DIY).', Diponegoro Journal of Accounting, 2(3), pp. 1-13.

Pramesti, I. G. A. R. and Wiratmaja, I. D. N. (2017) 'Pengaruh Fee Audit, Profesionalisme Pada Kualitas Audit Dengan Kepuasan Kerja Sebagai Pemediasi', E-jurnal Akuntansi Universitas Udayana, 18(1), pp. 616-645.

Pratama, I. I. M. and Merkusiwati, N. K. L. A. (2015) 'Pengaruh Time Budget Pressure, Risiko Kesalahan Audit, dan Masa Perikatan Audit terhadap Kualitas Audit pada Kantor Akuntan Publik di Daerah Bali', Jurnal Akuntansi, 11(1), p. 211-219.

Ratha, D. K. and Ramantha (2015) 'Pengaruh Due Professional Care, Akuntabilitas, Kompleksitas Audit, dan Time Budget Pressure Terhadap Kualitas Audit', Jurnal Akuntansi, 13(1), p. 311-339.

Saadah, K. (2016) 'Kualitas Audit: Studi Pengaruh Time Budget Pressuredan Independensi Auditor pada Kantor Akuntan Publik di Kota Bandung', Jurnal Akuntansi Keuangan dan Bisnis, 9(1), pp. 38-47.

Sanusi, S. M., Iskandar, T. M. and Poon, J. M. L. (2017) 'Effect of Goal Orientationand Task Complexity on Audit Judgement Performance', Malaysian Accounting Review, 6(2), p. 123-139.

Setyawati, S. M. and Rosiana, M. (2015) 'Inovasi Dan Keunggulan Kompetitif Sebagai Variabel Mediasi Pengaruh Orientasi Pasar Terhadap Kinerja Bisnis (Studi Empiris Pada Usaha Kecil Dan Menengah Di Purwokerto)', Jurnal Fakultas Ekonomi dan Bisnis Universitas Jenderal Soedirman, 5(1), pp. 3-18.

Valentina, E. (2017) Pengaruh Time Budget Pressure Terhadap Kualitas Audit dan Budaya Etis Sebagai Variabel Mediator (Studi Empiris pada Auditor KAP di Kota Jakarta). Universitas Diponegoro Semarang. 